УДК $327.5(581+549.1)$ «2014/2020»

DOI: $10.26693 /$ ahpsxxi2020.02.084

\title{
КОНФЛІКТОГЕННІСТЬ АФГАНСЬКО-ПАКИСТАНСЬКИХ ВІДНОСИН ЗА ПРЕЗИДЕНТСТВА А. ГАНІ
}

\author{
Ірина Тихоненко, \\ e-mail: irinavi2202@gmail.com \\ ORCID: https://orcid.org/oooo-ooo2-7716-085X \\ Чорноморсъкий національний університет імені Петра Могили, \\ Україна, 54оо3, м. Миколаїв, вул. 68 Десантників, 10 \\ Вероніка Уранова, \\ e-mail: nikauranova7@gmail.com \\ ORCID: https://orcid.org/oooo-ooo2-4656-3963 \\ Чорноморсъкий національний університет імені Петра Могили, \\ Украӥна, 540о3, м. Миколаїв, вул. 68 Десантників, 10
}

У статті здійснено аналіз динаміки конфліктогенності афганськопакистансъких відносин за президентства А. Гані, яка залежить від наступних чинників: 1) традиційні загрози - прикордонне питання та проблема Пуштуністану; 2) «нетрадиційні» загрози - питання біженців, наркотрафіку та фінансування тероризму; 3) постафгансъке врегулювання як у форматі АФганістан-«Талібан»-Пакистан, так і під впливом зовнішніх сил - США, Китаю та Індї. Автори дійшли висновку щодо залежності пакистансъко-афганської взаємодї від рівня довіри між державами, ефективності подолання загроз безпеці та впливу інших держав.

Ключові слова: Афганістан, Пакистан, США, «Талібан», Ашраф Гані, постафгансъке врегулювання

Постановка проблеми. Відносини між Ісламською Республікою Афганістан (IPA) та Ісламською Республікою Пакистан (IPП) мають тривалу історію та характеризуються низкою протиріч: від прикордонних суперечностей до питань афганських біженців і наркотрафіку. Зокрема, з приходом до влади в Афганістані президента А. Гані, афгансько-пакистанські відносини набули дещо нових змін, детермінантою яких стало їх входження у так званий період постафганського врегулювання, що ознаменувався інтенсифікацією політичного діалогу, відчутним впливом позарегіональних акторів на двосторонню взаємодію. Звинувачення афганською стороною Пакистану у підтримці терористів і тиску на внутрішньоафганський переговорний процес перманентно загострює двосторонні відносини, хоча останнім часом можна вести мову про те, що стан конфліктогенності поступово набуває рис конструктивного діалогу.

У вересні 2020 р. між Афганістаном і Пакистаном було покладено початок нового етапу взаємовідносин, зокрема й у постафганському врегулюванні - візит А. Абдулли, очільника Вищої ради національного примирення в Афганістані до Пакистану та його зустріч з Президентом Пакистану А. Алаві, прем'єр-міністром I. Ханом і начальником штабу армії Пакистану К. Баджвою. Результат візиту домовленість про сприяння, яке буде надавати Пакистан афганському народу у подоланні кризи та запевнення про повагу афганського суверенітету та незалежності зі сторони Пакистану'1.

${ }^{1}$ Pakistan, Afghanistan shake hands as they aim to end mistrust (2020, September 29). Al 
Ступінь наукової розробки проблеми. Серед українських дослідників аналізом зовнішньої політики Афганістану присвячені праці Н.О. Пророченко², О.С. Пархомчук і Д. Гринів 3 .

Конфліктогенність відносин Афганістану та Пакистану (прикордонне питання, проблема Пуштуністану) досить грунтовно розглядають російські науковці А.Ю. Умнов ${ }^{4}$, М. Шах 5 , А.В. Демидов ${ }^{6}$ О.Н. Новікова7 приділяє увагу саме постафганському врегулюванню.

Проблема біженців, наркотрафіку, тероризму, а також постафганське врегулювання стають об'єктом досліджень західних фахівців-міжнародників: В. ФлебабБраун $^{8}$, А. Паркес 9 , М. Юсуф, С. Сміт ${ }^{10}$.

Подекуди діаметральні позиції щодо об’єкту дослідження прослідковуються у наукових розвідках афганських і пакистанських науковців та політичних діячів А. Надері (відповідальний у справах України та країн Кавказу в третьому політичному Департаменті МЗС Афганістану)11, М. Уль Хамід, А. Хан, Р. Уллах (Малакандський університет, Пакистан) ${ }^{12}$.

Варто відзначити, що серед української наукової школи є недостатньо дослідженим питання афгансько-пакистанської взаємодії, конфліктогенності відносин саме за президентства А. Гані, що детермінується динамікою подій та актуалізує проблематику дослідження.

Мета статті полягає в аналізі характерних рис конфліктогенності відносин між Афганістаном і Пакистаном у період президентства А. Гані, а також виявленні позитивних та негативних тенденцій, що впливають на шляхи нормалізації двосторонніх відносин.

Виклад основного матеріалу. Афганістан і Пакистан є не лише ісламськими країнами, сусідами першого геополітичного порядку, а й досить тісно пов'язані між собою з огляду на історичні передумови. Адже, конфлікти та суперечності, які існують між державами, детермінують їх взаємовідносини у всіх сферах, а також впливають на регіональне безпекове середовище.

Jazeera. Retrieved from https://www.aljazeera.com/news/2020/9/29/in-islamabad-abdullahand-qureshi-strike-conciliatory-tone

2 Пророченко, Н.О. (2014). Іран, Афганістан, Пакистан як історичні субкультури Ісламського світу. Глобальна периферія в XXI ст.: засади, закономірності та умови цивілізаційного ренесансу. Збірник наукових праць / за загальною редакцією д.і.н. проф., Гури В.К. / Державна установа «Інститут всесвітньої історії НАН України», 290-326.

3 Пархомчук, О.С., Гринів Д. (2012). Регіональний вимір зовнішньої політики Афганістану. Актуальні проблеми міжнародних відносин, 108 (1), $23-28$.

4 Умнов, А. (2012). Афганистан-Пакистан: вчера и сегодня. Россия и мусульманский мир, 10, 96-99.

5 Шах, М. (2014). Пуштунский национализм в Афганистане и Пакистане. Россия и мусульманский мир, 11 (269), 114-123.

6 Демидов, А.В. (2020). Индия - Афганистан - Пакистан. «Стратегическая глубина» или стратегический охват? Архивариус, 5 (5o), 19-22.

7 Новикова, О.Н. (2020). Сложность мирного процесса в Афганистане. Актуальные проблемы Европы, 2, 173-194.

8 Felbab-Brown, V. (2016). The drug-conflict nexus in South Asia: beyond Taliban profits and Afghanistan. The Brookings Institution. Retrieved from https://www.brookings.edu/wpcontent/uploads/2016/06/o5_regional_counternarcotics_felbabbrown.pdf

9 Parkes, A. (2019). Considered Chaos: Revisiting Pakistan's 'Strategic Depth' in Afghanistan. Strategic Analysis, 43 (4), 1-10.

${ }^{10}$ Yusuf M. \& Smith S. (2015) Ashraf Ghani's Pakistan Outreach Fighting against the Odds. United State Institute for Peace. Retrieved from https://www.usip.org/sites/default/files/SR376Ashraf-Ghani-Pakistan-Outreach-Fighting-against-the-Odds.pdf

${ }^{11}$ Naderi, A. (2017). Modern political and socio-economic situation in Afghanistan. RUDN Journal of World History, 9 (4), 353-362.

${ }_{12}$ Ul Hamid M., Khan A. \& Ullah R. (2020). Pakistan's afghan policy: trends and prospects. Pakistan Journal of society, education and language, 6 (1), 113-127. 
Двосторонні афгансько-пакистанські відносини, у переважній більшості, характеризуються як конфліктогенні. Поняття «конфліктогенність» 3 латини «conflictus» - «зіткнення, боротьба, вороже відношення» та грецького «genesis» «поява, походження» означає здатність об’єкта породжувати конфлікт. Конфліктом є ситуація, коли учасники відносин поєднуються єдиним об’єктом, щодо якого існує несумісність їх інтересів. Американський науковець Л. Козер визначає політичний конфлікт як боротьбу за права щодо володіння статусом, ресурсами та силою. Конфлікт - активною конфронтаційною поведінкою сторін. Окрім поняття «політичний конфлікт» доречно виокремити «міжнародний конфлікт» - тривалий стан активної або пасивної боротьби двох або кількох акторів міжнародних відносин, що відбувається через відстоювання інтересів, які несумісні з інтересами іншої сторони ${ }^{13}$.

Тому, розглядаючи відносини між Афганістаном і Пакистаном варто зазначити, що обидві держави вступили у конфліктогенну фазу своїх відносин через зіткнення протилежних інтересів, а також небажання за певних умов знайти компроміс. Зазначимо, що президентство А. Гані асоціюється, насамперед, з внутрішньополітичним діалогом і постафганським врегулюванням, які безпосередньо детермінуються «пакистанським» фактором і залученням терористичної складової. Проте, на порядку денному залишаються й інші суперечності, які певним чином призводять до ескалації існуючого стану двосторонніх контактів або ж слугують інструментами зовнішньополітичного впливу однієї сторони на іншу.

Виділимо фактори, що призводять до зіткнення інтересів і загострення відносин між Афганістаном і Пакистаном за президентства А. Гані, зважаючи на загрози національній безпеці держав:

1. Історично обумовлені протиріччя, які можуть бути охарактеризовані як «традиційні» загрози безпеці (використання зброї та військової протидії): прикордонне питання та проблема Пуштуністану.

2. «Нетрадиційні» загрози - проблема афганських біженців і питання наркотрафіку та діяльність терористичних угрупувань, насамперед, «Талібану».

3. Постафганське врегулювання та переговорний процес у трикутнику інтересів Афганістан - «Талібан» - Пакистан, а також залучення зовнішніх сил США, КНР та Індія.

Варто акцентувати увагу на ролі, що відводиться двостороннім контактам i безпековій сфері у зовнішньополітичному курсі як Афганістану, так і Пакистану, які, незважаючи на низку протиріч, знаходяться у тісній взаємозалежності.

Вагомість Афганістану для Пакистану може бути розглянута крізь призму пакистанської концепції «стратегічної глибини» виробленої у Пакистані у 1980х pp., яка має на меті більш «глибоке» залучення Афганістану до зовнішньополітичних інтересів Ісламабаду. Зокрема, посол США у Пакистані Р. Олсен в одному 3 інтерв’ю зазначав, що Пакистан використовує концепцію «стратегічної глибини» у відносинах з Афганістаном, щоб контролювати Афганістан і тим самим маневрувати у відносинах з Індією14.

Ще на початку 1946 р. тодішній начальник Генерального штабу в Індії генерал А. Сміт зауважив, що через географічну близькість між майбутнім Пакистаном та Індостаном, Пакистану не вистачало «глибини, щоб забезпечити розташування основних баз поза зоною дії бомбардувальників противника». А. Сміт мав на увазі, що у разі несприятливих відносин 3 Індією, Пакистану доведеться шукати «глибини» в Афганістані та забезпечити гнучкий режим у Кабулі. У колоніальних військових термінах поняття «стратегічної глибини» означало геостратегічний

13 Козер, Л. (2006). Враждебность и напряженность в конфликтных отношениях. Социология власти, 6, 180-181.

${ }^{14}$ Imtiaz, G. (2012, August 7). The elusive alliance. Foreign Policy. Retrieved from https://foreignpolicy.com/2012/o8/o7/the-elusive-alliance/ 
вплив, а у XX ст. - оборонну концепцію. Тобто, Пакистан буде проводити політику, спрямовану на запобігання потрапляння Афганістану під іноземний вплив, який сприймається вороже. Прагнення до «стратегічної глибини» частково пояснює підтримку Пакистаном пуштунських племен в Афганістані, яка раціоналізує підтримку Пакистаном руху «Талібан», в якому домінують пуштуни ${ }^{15}$.

Ісламабад хотів би бачити у Кабулі близький собі уряд, який не буде перебувати в орбіті індійського впливу. У зв'язку з цим Пакистан прагне підірвати вплив Індії в Афганістані. Таким чином, Ісламабад руками спецслужб прагне забезпечити власний вплив в Афганістані й, одночасно, підірвати пуштунський сепаратизм на своїй території, який втілюється у проблему Пуштуністану16.

У свою чергу, влада Афганістану, зокрема, президент А. Гані, мають на меті збереження балансу між Пакистаном та Індією. Відповідно до засад зовнішньої політики А. Гані, яка складається з п’яти кіл щодо побудови відносин і взаємодії 3 регіональними країнами, Пакистан, як сусідня держава, залучена до першого кола, а Індія -четвертого ${ }^{17}$. На початку президентства у 2014 р. А. Гані також заявив, що розуміє стурбованість Ісламабаду щодо тісного зв’язку Індії з Афганістаном, однак налагодження відносин із сусіднім Пакистаном є важливішим для припинення конфліктного стану. Такі заяви були зроблені задля того, щоб покращити не лише політичну ситуацію між країнами, а й економічну, адже Пакистан залишається найбільшим торговим партнером для Афганістану18.

Важливим $є$ також те, що свій другий офіційний візит після обрання президентом А. Гані здійснив саме до Пакистану. Президент Афганістану, в порушення прийнятого протоколу, вирішив тоді особисто відправитися до вищого армійського керівництва - в офіс Генштабу пакистанської армії у Равалпінді, щоб обговорити досить напружені двосторонні відносини. Однак, конкретних результатів ця зустріч не дала, афганська сторона продовжила звинувачувати Пакистан у підтримці терористів. Офіційно було зроблено заяву про те, що допоки Ісламабад не буде виконувати обіцянки, то А. Гані не відвідає сусідню державу ${ }^{19}$. Тому двосторонні візити на найвищому рівнях і за участі профільних міністрів стають інструментами до зниження напруги між державами. Зазначимо, що А. Гані відвідав наступний раз Пакистан лише у 2019 р. ${ }^{20}$

Безперечно, обидві держави займають чільне місце у зовнішньополітичних пріоритетах одна одної й найважливішою сферою двостороннього співробітництва у подоланні конфліктогенності за президентства А. Гані є постафганське врегулювання й участь у ньому Пакистану. Проте, варто зазначити, що спроби реалізувати діалог між талібами й афганською владою за участі як Пакистану, так і інших держав розвиваються на тлі нерозв'язних питань між Кабулом та Ісламабадом.

По-перше, історично обумовлені протиріччя. Прикордонне врегулювання. «Лінія Дюранда», встановлена як кордон у 1893 р., виступає точкою зіткнення інтересів обох держав. Ще у 1949 р. Афганістан висунув протест щодо договору

15 Parkes, A. (2019). Considered Chaos: Revisiting Pakistan's 'Strategic Depth' in Afghanistan. Strategic Analysis, 43 (4), 2.

16 Демидов, А.В. (2020), 21.

17 Danish, Z. (2017, March 17). Objectives, Strategy and Structure of Decision-making in Afghanistan's foreign policy; from the Perspective of the Constitution and the President Mohammad Ashraf Ghani. Office of Chief of Staff for the President of the Islamic Republic of Afghanistan. Retriever from https://ocs.gov.af/en/article_details/52

18 Yusuf, M., Smith, S. (2015).

19 Джанбаз, Г. (2019, 9 июня). Президент Афганистана готовится к визиту в Пакистан. Независимая газета. Retrieved from https://ng-ru.turbopages.org/ng.ru/s/world/2019-o609/100_afganistano90619.html

${ }^{20}$ Gul, A. (2019, June 28). Ghani Seeks Pakistan's Support for Afghan Peace Talks With Taliban. Voice of America. Retrieved from https://www.voanews.com/south-central-asia/ghani-seekspakistans-support-afghan-peace-talks-taliban 
про афгансько-пакистанський кордон і визнав незаконність приєднання пуштунських земель до Пакистану. Президент А. Гані, як і колишні представники влади, дотримується позиції про неприйнятність «лінії Дюранда». Він вибудовує політику, намагаючись також враховувати сучасні реалії міжнародних відносин, а також міжетнічний фактор в Афганістані та питання про регіональну безпеку, що підтверджується прийнятою влітку 2017 р. двосторонньою угодою держав про проведення спільних операцій по «лінії Дюранда». Афганістан і Пакистан ведуть суперечки щодо визнання кордону офіційно. Крім того, Кабул звинувачує Ісламабад у підтримці сил «Талібану», які ведуть збройну боротьбу проти уряду Афганістану, що підтримується США. Пакистан заперечує надання такої підтримки²1.

Зазначимо, ще у 2014 р. Пакистан розпочав роботу щодо будівництва захисної лінії на кордоні з Афганістаном, але напруженість ситуації й активне залучення терористів ускладнило процес. У 2016 р. Ісламабад все ж таки завершив роботи на контрольно-пропускному пункті «Баб-е-Пакистан», апелюючи до зменшення нелегального транзиту як біженців, так і наркотрафіку, що викликало осуд з афганської сторони, яка вважає цю територію своєю. Вже у 2017 р. Пакистан заявив, що розпочав будівництво огорожі вздовж кордону, а на початку грудня 2020 р. пакистанські військові заявили, що протягом найближчих двох місяців закінчать процес відгородження приблизно 2600-кілометрового історичного кордону з Афганістаном. Міністр закордонних справ країни Ш.М. Куреші зазначив, що огородження дозволить запобігти незаконному переходу та зменшить проникнення терористів. Проект на 500 мільйонів доларів складається з двох дротяних огорож висотою 9 футів, розділених 6-футовим зазором з колючого дроту. Пакистанська армія також встановила 843 прикордонні пости вздовж лінії огорожі 22.

Зазначимо, що перманентно між афганськими та пакистанськими військовими відбуваються обстріли на кордоні. Наприклад, у 2018 р. відбувся збройний конфлікт після того, як пакистанські військові намагались захопити контрольно-пропускний пункт афганських прикордонників у населеному пункті Зазай-Майдан 23.

Зокрема, лише у 2020 р. в результаті прикордонного зіткнення в районі Спін Болдак у Кандагарі напередодні свята Курбан-байраму було вбито майже 15 афганців і 80 людей поранено. В іншому подібному інциденті з пакистанської сторони - 30 липня 2020 р. троє людей загинули та понад 20 отримали поранення після сутичок, що сталися на прикордонному переході «Ворота дружби» в місті Чаман, провінція Белуджистан 24.

Проблема Пуштуністану. Афганська сторона критикує дії Пакистану щодо будівництва прикордонної огорожі, стверджуючи, що він не лише порушує ії кордон, а й розділяє сім’ї пуштунів, які живуть на прикордонній території. Пуштуни $\epsilon$ найбільшим етносом в Афганістані, а також чисельно проживають у Пакистані на прикордонних з Афганістаном землях у провінції Хайбер-Пахтунхва та мають ідею створення окремого державного утворення «Великий Пуштуністан» 25.

${ }^{21}$ Sharif, Amiri (2017, July 5). Pakistan To Conduct Joint Ops With Afghanistan Along Durand Line. TOLOnews. Retrieved from https://tolonews.com/afghanistan/pakistan-conduct-joint-opsafghanistan-along-durand-line

${ }^{22}$ Noorzai R. (2020, December 18). Pakistan Border Fencing Disrupts Local Trade in Chaman. Voice of America. 2020. Retrieved from https://www.voanews.com/extremism-watch/pakistanborder-fencing-disrupts-local-trade-chaman

23 На линии Дюранда вспыхнули бои между афганскими и пакистанскими военными (2018). НВ. Інтерфакс-Украӥна. Retrieved from https://nv.ua/world/geopolitics/na-liniidjuranda-vspykhnuli-boi-mezhdu-afhanskimi-i-pakistanskimi-voennymi-2464263.html

${ }^{24}$ It's not just India, Pakistan also covets the Afghanistan borderlands. (2020, October 16). The Economic Times. Retrieved from https://economictimes.indiatimes.com/news/defence/its-notjust-india-pakistan-also-covets-the-afghanistan-

borderlands/articleshow/78697080.cms?from $=\mathrm{mdr}$

25 Умнов, А. (2012), 28. 
Зазначимо, що саме з 2014 р. пуштуни у Пакистані створили правозахисний pyx Pashtun Tahafuz Movement (РТM), який розгорнув активну діяльність проти пакистанської влади, а також військових, які на прикордонній території проводять антитерористичні операції. Зокрема, на початку 2018 р. відбувся так званий «пуштунський марш» на чолі з М. Паштіном. Ця подія також отримала назву «пуштунська весна». Афганський уряд, який зазвичай утримується від коментарів щодо внутрішньої політики Пакистану, високо оцінив кампанію лідера РТМ М. Паштіна. Президент Афганістану А. Гані поділився кількома твітами про «пуштунський марш» у лютому 2018 р., сподіваючись, що цей рух сприятиме «викоріненню тероризму з регіону». У свою чергу, Ісламабад звинуватив Афганістан та Індію у підтримці цього руху й антидержавницьких заходів у Пакистані 26 . Зауважимо, що за умови реалізації проєкту «Великого Пуштуністану» буде порушена територіальна цілісність як Пакистану, так і Афганістану

По-друге, питання наркотрафіку та проблема афгансъких біженців. Варто наголосити, що пуштуни тісно пов'язані з питанням транзиту наркотичних речовин між Афганістаном і Пакистаном. Адже, крім пуштунів, що проживають по обидві сторони афгансько-пакистанського кордону, зокрема у Пакистані - провінція Хайбер-Пахтунхва та Зона племен, на прикордонній території розташовані табори афганських біженців, а також ці території виступають місцем дислокації терористичних організацій - «Талібан», «Техрік-і-Талібан-Пакистан», «Мережі Хаккані» тощо.

За даними Управління Верховного комісара ООН у справах біженців (УВКБ $\mathrm{OOH}$ ) станом на 2020 р. в Пакистані проживають близько 2,8 млн. біженців з Афганістану. Однією з пріоритетних задач всі ці роки було повернення біженців додому. Однак, зараз програма репарації тимчасово припинена через Covid-19. До оголошення епідемії та карантину, лише за січень 2020 р. 665 осіб повернулись в Афганістан. Проте, незважаючи на голосні заяви прем'єр міністра Пакистану I. Хана про те, що афганці легко інтегрувались у життя пакистанців, стали їм друзями та вважають Пакистан своїм домом - багато з них працюють на тяжких, брудних роботах, мають погані умови для життя, страждають від голоду та хвороб. Наразі існує така тенденція - міжнародне співтовариство залишається заручником політики Пакистану в Афганістані. Таким чином спільнота балансує, висуваючи суперечливі вимоги - вимагає більш гуманного поводження з біженцями, одночасно наполягаючи на боротьбі з тероризмом, якому сприяє Пакистан 27.

Питання афганських біженців у відносинах між Пакистаном та Афганістаном неможливо розглядати без процесу репатріації біженців до Афганістану, на якому не лише наполягає Пакистан, а й за яким слідкує УВКБ ООН. Незважаючи на те, що Пакистан та ООН поступово реалізують процес повернення афганців на батьківщину, проблема стоїть дуже гостро. Беручи до уваги процес постафганського врегулювання та звинувачення зі сторони офіційного Кабулу у підтримці терористів зі сторони Пакистану, офіційний Ісламабад неодноразово наголошував на примусовій репатріації біженців до Афганістану. Такі дії пов’язанні зокрема із політикою А. Гані на зближення з Індією. Тому, у 2014 р. після теракту у Пешаварі, Пакистан оголосив про примусову репатріацію біженців до кінця 2015 р., проте у результаті політичних консультацій, у питанні біженців Ісламабад погодився про-

\footnotetext{
${ }^{26}$ Shah, M, Jillani, S. (2019, June 5). Pashtun movement leader: 'Pakistani army is afraid of our popularity'. Deutsche Welle. Retrieved from https://www.dw.com/en/pashtun-movementleader-pakistani-army-is-afraid-of-our-popularity/a-49069682

27 The UN Refugee Agency (2020). Four decades and counting: An urgent need to rekindle hope for millions of Afghan refugees. Retrieved from https://www.unhcr.org/news/briefing/2020/2/5e4272d64/four-decades-counting-urgent-needrekindle-hope-millions-afghan-refugees.html
} 
довжити дію реєстраційних свідоцтв, які вже видані афганцям 331 грудня 2015 р. до 31 грудня 2017 р. ${ }^{28}$

Перманентні погрози щодо репатріації та поступовий діалог між державами триває і наразі, що пов'язано із залученням афганських біженців до процесу наркотрафіку та терористичної діяльності і нелегального продажу зброї.

Важкодоступність районів, через які проходить кордон, є одним з декількох факторів, які ускладнюють роботу афганських і пакистанських прикордонників і наркополіцейських з блокування потоку заборонених речовин. Інші фактори, що ще більше обтяжують становище, включають неврегульований статус кордону, традиційну недовіру один до одного політичних еліт і збройних сил Афганістану та Пакистану29.

Зокрема, 17 лютого 2020 р. другий віце-президент Афганістану С. Даніш заявив на конференції, присвяченій афганським біженцям в Ісламабаді, що Пакистан дозволив талібам вербувати афганських біженців до своїх лав. Прем'єрміністр Пакистану заперечив ці звинувачення, але заявив, що не можна відкидати, що бойовики ховаються серед населення біженців ${ }^{30}$.

У свою чергу, Афганістан і Пакистан, відчуваючи негативний вплив терористичної діяльності, мають діяти разом, зважаючи на можливе поширення на їх територію діяльності «Ісламської держави»31.

Постафгансъке врегулювання. Враховуючи нестабільність ситуації у безпековій сфері в Афганістані i, найголовніше, роль Пакистану як ключового гравця у підтримці талібів, зближення уряду А. Гані з пакистанською стороною з метою переконати талібів відмовитися від насильства здавалося цілком імовірним. Коли новообраний президент вчинив певні кроки, щоб продемонструвати свою щирість у поліпшенні відносин з Пакистаном, афганці почали ставитися до цих зусиль 3 обережністю та скептицизмом. На думку багатьох аналітиків, мета А. Гані полягає у тому, щоб включити талібів у політичну систему, для чого Афганістан повинен бути у мирі та злагоді з Пакистаном. Крім того, щоб «посадити» талібів за стіл переговорів, Афганістан повинен провести реформи та здійснити необхідні політичні зміни в уряді ${ }^{2}$.

У липні 2015 р. представники «Талібану» почали в Пакистані офіційні переговори з представниками афганського уряду. Проте, ці переговори були незабаром згорнуті, оскільки надійшла звістка, що лідер цієї терористичної організації Мулла М. Омар вже кілька років як помер. Потім була сформована чотиристороння координаційна група у складі Афганістану, Пакистану, США та Китаю для підготовки мирних переговорів. Ініціатори цього процесу розраховували, що одна 3 частин угруповання «Талібан» погодиться на переговори. Проте, навіть «відступник» у середовищі талібів Мулла М. Расул, який на той час контролював до 10\% збройних сил талібів, заявив, що готовий брати участь у переговорах тільки після виведення з Афганістану всіх іноземних військ. Були надії на те, що Пакистан

28 Тихоненко, І.В. (2016). Наркоторгівля та проблема біженців у пакистансько-афганських відносинах. Наукові праці. Серія: Політологія, 273 (261), 99-10о.

29 Gardesh, H. (2012). Afghans Say Pakistan behind Cross-border Fire. Institute for War and Peace Reporting. Retrieved from https://iwpr.net/global-voices/afghans-say-pakistan-behindcross-border-fire

$3^{\circ}$ European Asylum Support Office (2020). Pakistan Situation of Afghan refugees Country of Origin Information Report. Retrieved from https://www.ecoi.net/en/file/local/2030503/05_2020_EASO_COI_Report_Pakistan_Situation of_Afghan_Refugees.pdf

${ }_{31}^{1}$ Ul Hamid M., Khan A. \& Ullah R. (2020), 125.

32 Partaw, A.M. (2015, July 28). The Dynamics of Peace and Political Change in Afghanistan. Foreign Policy Journal. Retrieved from https://www.foreignpolicyjournal.com/2015/07/28/thedynamics-of-peace-and-political-change-in-afghanistan/ 
«натисне» на талібів з метою зробити їх поступливішими, але вже в березні 2016 р. «Талібан» відмовився брати участь у переговорах 33.

10 грудня 2015 р. відбулась конференція «Серце Азї - стамбульський процес» в Ісламабаді, участь в якій взяв і А. Гані. Важливим кроком стала пропозиція А. Гані, адресована талібам, сісти за стіл переговорів з метою вироблення загальних норм стабілізації внутрішньополітичної ситуації. Виступаючи на заході, експрем'єр-міністр Пакистану Н. Шаріф зобов'язався вжити заходів для протидії бойовикам, які готують атаки проти Афганістану на території IPП. У свою чергу, А. Гані пообіцяв вести боротьбу з пакистанськими талібами, що підтримують активність у східних афганських провінціях 34 .

Наприкінці 2015 р. була сформована чотиристороння контактна група, у складі якої були Китай, США, Афганістан і Пакистан. Вона мала полегшити перемовини між талібами й Афганістаном, група провела декілька засідань. Однак ці зустрічі ні до чого не привели через зростаючу недовіру між Афганістаном і Пакистаном, а також через нечітку позицію самих талібів. На самому початку афганська влада орієнтувалася на ситуацію у пакистансько-індійських відносинах і намагалася одночасно налагодити перемовини 3 талібами, але транскордонні обстріли з обох сторін і вбивства військовослужбовців призвели до звинувачень на адресу Пакистану та порушили співпрацю. Таліби розглядають себе як владу у вигнанні та не мають бажання домовлятись 35.

У 2019 р. А. Гані вдруге відвідав Пакистан. Метою цього візиту було провести переговори з керівництвом Пакистану - прем'єр-міністром I. Ханом і його командою щодо взаємодії з талібами. А. Гані наполягав на тому, щоб Ісламабад вмовив талібів піти на переговори з Кабулом. «Пакистан відіграє важливу роль: і між «Талібаном» і Пакистаном існує сильна взаємозалежність. Ми повинні визнати це і виробити програмні підходи для переходу від конфлікту до співпраці», - заявив афганський лідер. У свою чергу, міністр закордонних справ Пакистану Ш.М. Куреші заявив: «Ми будемо заохочувати і сприяти внутрішньоафганському діалогу, який, на нашу думку, необхідний для примирення, і постараємося завоювати довіру один одного»36.

Вже у вересні 2020 р. відбувся візит очільника Вищої ради національного примирення в Афганістані А. Абдулли до Пакистану та його зустріч з Президентом Пакистану А. Алаві, прем'єр-міністром І. Ханом і начальником штабу армії Пакистану К. Баджвою, яка ознаменувала новий етап у взаємовідносинах між державами. Зокрема, було наголошено на наданні зі сторони Пакистану сприяння Афганістану у мирному врегулюванні, проте, без одноосібної підтримки жодної сторони більш, ніж це вимагає мирний процес. Адже Пакистан, насамперед його прикордонні з Афганістаном території, теж страждають і залежать від діяльності «Талібану» й офіційний Ісламабад має знаходити спільну мову не лише з владою Афганістану, а й з талібами 37.

Можна стверджувати, що між Афганістаном і Пакистаном існує геополітичновизначений детермінізм, проте процес постафганського врегулювання безпечно буде відчувати об’єктивний вплив зовнішніх сил.

На афганський мирний процес впливає і позиція регіональних і деяких поза-

33 Новикова, О.Н. (2020), 175.

34 Zain, A. (2015). Pakistan, Afghanistan to jointly host 'Heart of Asia Conference'. Daily Pakistan. Retrieved from https://en.dailypakistan.com.pk/10-Nov-2015/pakistan-afghanistanto-jointly-host-heart-of-asia-conference-on-december-7

35 Fisas, V. (2015). 2015 yearbook of peace processes. Romanyà Valls, SA, 126-132. Retrieved from https://peacemaker.un.org/sites/peacemaker.un.org/files/YearbookPeaceProcesses-ECP2015.pdf

${ }^{36}$ Gul, A. (2019, June 28).

37 Pakistan, Afghanistan shake hands as they aim to end mistrust (2020, September 29). 
регіональних держав. Саудівська Аравія, Іран і Туреччина, безсумнівно, хотіли б грати більш важливу роль в афганському мирному врегулюванні, однак вони більше конкурують один з одним і не в змозі виступити єдиним фронтом. Китай продовжує відігравати важливу роль у регіоні, надаючи дозований вплив на позицію Пакистану та виступаючи за впорядковане виведення іноземних військ 3 Афганістану з метою встановлення стійкого перехідного періоду в країні. Головними важелями впливу США в Афганістані залишаються військова присутність і фінансова допомога. Вашингтон має намір продовжити переговори 3 «Талібаном», висунувши конкретні вимоги до умов миру 38 .

Взимку 2019 р. в Катарі проходив черговий раунд переговорів між США і «Талібаном». Сполучені Штати заявляють, що погодяться вивести свої бойові частини 3 IPA, тільки якщо «Талібан» почне переговори з афганським урядом і погодиться на тривалий період припинення вогню. При цьому, представник США 3 питань Афганістану 3. Халілзад підкреслив, що американці будуть підходити до досягнення домовленостей за принципом «нічого не вирішено до тих пір, поки все не вирішено». У свою чергу, «Талібан» наполягає, поки не вирішено питання про виведення іноземних військ з Афганістану, неможливий прогрес у розгляді інших проблем 39.

Деякі експерти охарактеризували зустрічі між США і «Талібаном» у переважній більшості як «переговори заради переговорів». 3 доповіді дослідницької служби Конгресу США можна зробити висновок, що контакти американців з талібами носили конфіденційний характер і не були офіційно підтверджені американською стороною. Проте, адміністрація Д. Трампа, з огляду на передвиборчу кампанію, перейшла від конфіденційних контактів до офіційних переговорів40.

Однак, не можна стверджувати про значні зрушення у переговорному процесі у 2020 р., адже таліби перманентно атакують південь Афганістану. Ще у лютому 2020 р. Вашингтон і «Талібан» підписали угоду про припинення вогню. Після цього американський контингент різко знизив підтримку армії Афганістану, чим викликав невдоволення А. Гані. Відповідно до домовленостей, американці до травня 2021 р. мають вивести свій контингент. В обмін на це таліби пообіцяли не використовувати Афганістан, як територію для організації терористичних атак ${ }^{41}$.

Варто зауважити, що активізація США у постафганському врегулюванні має враховувати динаміку відносин Афганістан-Пакистан, на які впливає комплекс неврегульованих питань, а Ісламабад, маючи стратегічні національні інтереси на афганському напрямі, навряд чи поступиться своєю роллю у мирному врегулюванні у сусідній державі.

Висновки: Афгансько-пакистанські відносини за президентства А. Гані в Афганістані можуть бути охарактеризовані крізь призму низки факторів, що детермінують конфліктогенність міждержавної взаємодії:

неврегульованість питання афгансько-пакистанського кордону та проблема Пуштуністану. Зокрема, майже завершення Пакистаном будівництва стіни на кордоні з Афганістаном, ставить під сумнів майбутню «дружню» розбудову двосторонніх відносин. Проте, можлива перспектива утворення «Великого Пуштуністану» має сприяти політичному діалогу між державами;

\footnotetext{
$3^{8}$ Афганистан, Пакистан и Китай обсудили мирный процесс и борьбу с терроризмом (2019). Afghanistan.ru. Retrieved from http://afghanistan.ru/doc/132457.html/

39 Duan, A. (2019, August 14). Can U.S.-Taliban peace talks end the war in Afghanistan? Council on Foreign Relations. Retrieved from https://www.cfr.org/in-brief/can-us-taliban-peace-talksend-war-afghanistan

$4^{\circ}$ Congressional Research Service (2018). Momentum Toward Peace Talks in Afghanistan? Retrieved from https://crsreports.congress.gov/product/pdf/IN/IN10935/

${ }^{41}$ Congressional Research Service (2020). Afghanistan: Background and U.S. Policy: In Brief. Retrieved from https://fas.org/sgp/crs/row/R45122.pdf
} 
- існуюча залежність обох держав від проблеми біженців, наркотрафіку та тероризму. Якщо питання біженців є певним чином засобом тиску Пакистану на Афганістан через процес примусової репатріації, то наркотрафік і тероризм мають сприяти взаємодії урядів обох держав. Проте, і за президентства А. Гані не вдалося наразі значно підвищити рівень довіри до пакистанської сторони, що простежується у звинуваченнях Пакистану щодо підтримки терористів.

з приходом до влади у 2014 р. А. Гані, відносини між державами набули більш конструктивного характеру, детермінантою якого стало постафганське врегулювання. Пакистан неодноразово наголошував на сприянні мирному врегулюванні, проте, за шість років позиція талібів залишається незмінною - вони не підтримують владу Кабулу, не бажають підкорятись умовам США, не визнають свою діяльність, як терористичну. У свою чергу Пакистан, відповідно до позиції Афганістану, підтримує рух «Талібан», укриває різні терористичні угрупування, а на міжнародній арені показує себе, як держава-захисник, що допомагає афганським біженцям.

Таким чином, можна стверджувати, що афгансько-пакистанські відносини за президентства А. Гані мають певні здобутки у конструктивному діалозі (зустрічі лідерів держав, спільні заяви про взаємодопомогу), але не набули кардинальних зрушень у врегулюванні протиріч, адже, не лише кожна з держав відстоює національні інтереси, а й підпадає під вплив «вищих» союзників, що негативно відображається на двосторонній взаємодії.

\section{REFERENCES}

Afganistan Pakistan i Kitai obsudili mirnyi protsess i borbu s terrorizmom [Afghanistan, Pakistan and China discussed the peace process and the fight against terrorism]. (2019). Afghanistan.ru. Retrieved from http://afghanistan.ru/doc/132457.html/ [in Russian].

Danish, Z. (2017, March 17). Objectives, Strategy and Structure of Decision-making in Afghanistan's foreign policy; from the Perspective of the Constitution and the President Mohammad Ashraf Ghani. Office of Chief of Staff for the President of the Islamic Republic of Afghanistan. Retriever from: https://ocs.gov.af/en/article_details/52 [in English].

Demidov, A.V. (2020). Indiia-Afganistan-Pakistan Strategicheskaia glubina ili strategicheskii okhvat [India-Afghanistan-Pakistan. «Strategic depth» or strategic reach?]. Arkhivarius, 5 (50), 19-22 [in Russian].

Dzhanbaz, G. (2019, 9 iiunia). Prezident Afganistana gotovitsia k vizitu v Pakistan [Afghan President prepares for visit to Pakistan]. Nezavisimaia gazeta. Retrieved from https://ngru.turbopages.org/ng.ru/s/world/2019-06-09/100_afganistano90619.html [in Russian].

Duan, A. (2019, August 14). Can U.S.-Taliban peace talks end the war in Afghanistan?. Council on Foreign Relations. Retrieved from https://www.cfr.org/in-brief/can-us-taliban-peacetalks-end-war-afghanistan [in English].

Felbab-Brown, V. (2016). The drug-conflict nexus in South Asia: beyond Taliban profits and Afghanistan. The Brookings Institution. Retrieved from https://www.brookings.edu/wpcontent/uploads/2016/06/o5_regional_counternarcotics_felbabbrown.pdf [in English].

Fisas, V. (2015). 2015 yearbook of peace processes. Romanyà Valls, SA. Retrieved from https://peacemaker.un.org/sites/peacemaker.un.org/files/YearbookPeaceProcesses-ECP2015.pdf [in English].

Gardesh, H. (2012). Afghans Say Pakistan behind Cross-border Fire. Institute for War and Peace Reporting. Retrieved from https://iwpr.net/global-voices/afghans-say-pakistanbehind-cross-border-fire [in English].

Gul, A. (2019, June 28). Ghani Seeks Pakistan's Support for Afghan Peace Talks With Taliban. Voice of America. Retrieved from https://www.voanews.com/south-central-asia/ghani-seekspakistans-support-afghan-peace-talks-taliban [in English].

Imtiaz, G. (2012, 7 August 2012). The elusive alliance. Foreign Policy. Retrieved from https://foreignpolicy.com/2012/08/o7/the-elusive-alliance/ [in English].

Kozer, L. (2006). Vrazhdebnost i napriazhennost v konfliktnykh otnosheniiakh [Hostility and tensions in conflict relationships]. Sotsiologiia vlasti, 6, 175-186 [in Russian].

Naderi, A. (2017). Modern political and socio-economic situation in Afghanistan. RUDN Journal of World History, 9 (4), 353-362 [in English]. 
Noorzai, R. (2020, December 18). Pakistan Border Fencing Disrupts Local Trade in Chaman. Voice of America. Retrieved from https://www.voanews.com/extremism-watch/pakistanborder-fencing-disrupts-local-trade-chaman [in English].

Novikova, O.N. (2020). Slozhnost mirnogo protsessa v Afganistane [The complexity of the peace process in Afghanistan]. Aktualnye problemy Evropy, 2, 173-194 [in Russian].

Parkes, A. (2019). Considered Chaos: Revisiting Pakistan's 'Strategic Depth' in Afghanistan. Strategic Analysis, 43 (4), 1-10 [in English].

Parkhomchuk, O.S. \& Hryniv, D. (2012). Rehionalnyy vymir zovnishnioyi polityky Afhanistanu [The regional dimension of Afghanistan's foreign policy]. Aktualni problemy mizhnarodnykh vidnosyn, 108 (1), 23-28 [in Ukrainian].

Partaw, A.M. (2015, July 28). The Dynamics of Peace and Political Change in Afghanistan. Foreign Policy Journal. Retrieved from https://www.foreignpolicyjournal.com/2015/07/28/the-dynamics-of-peace-and-politicalchange-in-afghanistan/ [in English].

Prorochenko, N.O. (2014). Iran, Afhanistan, Pakystan yak istorychni subkultury Islamskoho svitu [Iran, Afghanistan, Pakistan as historical subcultures of the Islamic world]. Hlobalna peryferiya $v$ XXI st.: zasady, zakonomirnosti ta umovy tsyvilizatsiynoho renesansu. Zbirnyk naukovykh prats, 290-326 [in Ukrainian].

Shah, M. \& Jillani, S. (2019. June 5). Pashtun movement leader: 'Pakistani army is afraid of our popularity'. Deutsche Welle. Retrieved from https://www.dw.com/en/pashtunmovement-leader-pakistani-army-is-afraid-of-our-popularity/a-49069682 [in English].

Shakh, M. (2014). Pushtunskii natsionalizm v Afganistane i Pakistane [Pashtun nationalism in Afghanistan and Pakistan]. Rossiia i musulmanskii mir, 11 (269), 114-123 [in Russian].

Sharif, Amiri (2017, July 5). Pakistan To Conduct Joint Ops With Afghanistan Along Durand Line. TOLOnews. Retrieved from https://tolonews.com/afghanistan/pakistan-conduct-jointops-afghanistan-along-durand-line [in English].

Tykhonenko, I.V. (2016). Narkotorhivlia ta problema bizhentsiv u pakystansko-afhanskykh vidnosynakh [Drug trafficking and the refugee problem in Pakistani-Afghan relations]. Naukovi pratsi. Seriia: Politolohiia, 273 (261), 97-102 [in Ukrainian].

Ul Hamid, M., Khan, A. \& Ullah, R. (2020). Pakistan's afghan policy: trends and prospects. Pakistan Journal of society, education and language, 6(1), 113-127. Retrieved from https://pjsel.jehanf.com/index.php/journal/article/view/73 [in English].

Umnov, A. (2012). Afganistan-Pakistan: vchera i segodnia [Afghanistan-Pakistan: yesterday and today]. Rossiia i musulmanskii mir, 10, 96-99 [in Russian].

Yusuf, M. \& Smith, S. (2015). Ashraf Ghani's Pakistan Outreach Fighting against the Odds. United State Institute for Peace. Retrieved from https://www.usip.org/sites/default/files/SR376-Ashraf-Ghani-Pakistan-Outreach-Fightingagainst-the-Odds.pdf [in English].

Zain, A. (2015). Pakistan, Afghanistan to jointly host 'Heart of Asia Conference'. Daily Pakistan. Retrieved from https://en.dailypakistan.com.pk/10-Nov-2015/pakistan-afghanistan-tojointly-host-heart-of-asia-conference-on-december-7 [in English].

Iryna Tykhonenko, Petro Mohyla Black Sea National University, Mykolaiv, Ukraine ORCID: https://orcid.org/oooo-0002-7716-085X

Veronika Uranova, Petro Mohyla Black Sea National University, Mykolaiv, Ukraine ORCID: https://orcid.org/oooo-0oo2-4656-3963

\section{Conflictogenic nature of Afghan-Pakistan relations under the presidency of A. Ghani}

The article attempts to analyze the dynamics of conflict nature in AfghanistanPakistan relations during the presidency of A. Ghani, which depends primarily on the implementation of security threats.

The conflictofenic nature of the relations between Afghanistan and Pakistan can be 
discovered by several factors. Firstly, traditional threats to the security of the states are based on two issues - the Pashtun issue (the "Greater Pashtunistan» project may violate the territorial integrity of both states) and the unresolved passage of the Afghan-Pakistani border (non-recognition of the border by Afghanistan and the construction of a wall by Pakistan as its recognition).

Secondly, non-traditional threats such as the problem of refugees, drug trafficking and terrorism. If the refugee issue is in some way as Pakistan's pressure on Afghanistan through the process of forced repatriation, it has been found that countering drug trafficking and terrorism have facilitated cooperation between the governments of the two countries.

Thirdly, main change in bilateral relations depends on the negotiation processes and Post-Afghan settlement with the intervention of third States in this difficult situation (US, China, India). A peaceful settlement is implemented by AfghanistanTaliban-Pakistan negotiation with US participation as well. Taliban do not support the Kabul government, do not want to submit to US conditions, do not recognize their activities as terrorist. In turn, Pakistan, in line with Afghanistan's position, supports the Taliban, that reduces the level of trust between states.

The authors concluded that Afghan-Pakistan cooperation under the Presidency of Ashraf Ghani has a certain constructivism in the negotiations and political dialog. However, Afghanistan continues to depend on the influence of other states, including Pakistan, and needs attempts to negotiate not only from one side and to be more independent.

Keywords: Afghanistan, Pakistan, USA, Taliban, Ashraf Ghani, Post-Afghan settlement process 